\title{
Exploiting Public Art, Architecture and Urban Design for Political Power in Abuja: Modernism and the Use of Christian, Islamic and Ancestral Visual Icons
}

\author{
Nnamdi Elleh, David J. Edelman \\ University of Cincinnati, Cincinnati, USA \\ Email: david.edelman@uc.edu \\ Received $* * * * * * * * * 2013$
}

\begin{abstract}
Can public art, architecture and urban design be indices of the social, economic and political struggles for hierarchies and dominance among contesting interest groups within a postcolonial society like Nigeria? In 1975, the Nigerian military proposed that building a new Federal Capital Territory at Abuja would facilitate the country's "federal character" resolve the problem of nepotism, and ease ethnic tensions among the two hundred and fifty cultural groups which constitute the nation (Afigbo, 1986; Ajayi, 1984) ${ }^{1}$. However, a study of the architecture and the sculptures at the newly constructed National Assembly Complex suggest otherwise. In this paper, it is argued that while the ideology of a nationalist architecture and the concept of a "federal character" might have merit for a multi-ethnic society like Nigeria, at Abuja, "federal character" instead became the means with which the emergent postcolonial elite consolidated its economic and political power through the exploitation of public art, as well as Modernist architectural and urban design elements using Islamic, Christian, and Ancestral visual icons.
\end{abstract}

Keywords: Abuja; African Art; Architecture and Urban Design; African Religious Symbolism; Nigerian Politics

\section{Introduction}

Given that no city, let alone Abuja, Nigeria's modern capital city designed in the 1970s and built in the 1980s and 1990s, could be expected to achieve the broad egalitarian goals indicated by the postcolonial Nigerian authorities, what was achieved instead? Why would the idea that architecture and urban design might deliver such goals be imagined in Nigeria in 1975, the time when the building and the inaugural experiences of Brasília (Brazil), Chandigarh (India), Dodoma (Tanzania), and Islamabad (Pakistan) had been receiving mixed reviews from the architectural and urban design community, as well as from politicians and social critics (Evenson, 1973; Epstein, 1973; Kalia, 1987; Holston, 1989; Vale, 1992; Dovey, 1999)? How did certain Modernist inspired architectural and urban design

${ }^{1}$ The terms "federal character" and national unity and identity suggest that the country is not fully unified as the leaders and citizens would like it to be. That is not surprising since the country is a British creation. Within the political lexicon of the country, Nigeria's "federal character" refers to the "distinct desire of the peoples of Nigeria to promote national unity, foster national loyalty and give every citizen of Nigeria a sense of belonging to the nation notwithstanding the diversities of ethnic origin, culture, language or religion which may exist and which it is their desire to nourish, and harness to the enrichment of the Federal Republic of Nigeria”. In principle, it implies equitable distribution of political power and national wealth but that is hardly the case.

People from different ethnic, linguistic, religious, and cultural value systems were forced to become members of one nation by the British in 1914, the period of consolidation of colonialism. There is severe competition for the control of the political and economic resources of Nigeria between the different ethnic groups. elements utilizing Christian, Islamic and Ancestral modes of visual representation, accompanied by public art, become instruments of economic and political struggle among the postcolonial Nigerian ruling elite at Abuja? Answering these questions is the objective of this paper. This will be accomplished by first, explaining the political setting surrounding the decision to relocate the capital, second, discussing how Modernism, as well as Christian, Islamic, and Ancestral Visual Icons, were used to contest economic and political power at Abuja, third, reviewing the struggle for economic and political dominance at the critical central Three Arms Zone of Abuja, fourth, integrating the analysis provided by the three previous sections and, finally, summarizing the findings of the study.

\section{Prelude to the Battle: Relocating the Federal Capital from Lagos to Abuja}

When the Nigerian authorities proposed to build a new federal capital city at Abuja in 1975, the economy of the country was booming with oil revenues. The oil embargo against the "West" by the members states of the Organization of Petroleum Exporting Countries (OPEC), of which Nigeria is a member, had quadrupled the national revenue of the country, which once depended on the export of agricultural produce such as cocoa, palm oil, rubber, cassava, yam, cattle, leather, and different kinds of tropical fruit (Second National Development Plan, 19701974; Third National Development Plan, 1975-1980; Fourth National Development Plan, 1981-1985; Aadekson, 1981; Tay- 
lor, 1993$)^{2}$. In 1975, the petroleum based economy provided the basis for a new way of thinking about the development of the country. That new way of thinking envisioned architecture and urban design as a solution to socio-political problems, which the country's leaders, mainly a succession of military juntas, could not solve at the negotiating table. At that time, the reasoning was that if the socio-political problems of the country were to be solved, the starting point was at the capital of the nation, Lagos, located at the southwest corner of the Atlantic coast of the country. In order to implement the most important aspects of the development problems confronting the country, the Nigerian authorities encouraged their citizens to re-examine the role of Lagos as both the federal capital and the capital of the State of Lagos (Aguda Committee, 1975; Benson, 1975; Onun, 1975; Eke, 1975; Afilakalaka, 1975; Omumu \& BojiBoji, 1975) ${ }^{3}$. Questioning the suitability of Lagos as the capital of the country was not at all new, although the military leaders wanted the citizens to believe otherwise in 1975. In fact, the role of the city as the capital of the country had been in question from the time the country was founded in 1914 through 1960, when Nigeria became an independent state. In 1974, when the debate for the relocation of the Federal Capital was at its peak, Ishaya Audu, the then Vice Chancellor of Ahmadu Bello University, Nigeria, wrote that, "Firstly, our attention is drawn to the fact that this discussion has gone on since the creation of Nigeria as one political entity, contrary to the belief of some that the issue has only arisen as a result of recent manifestations of physical congestion (Audu, 1974)." In order to underscore the point that the idea of overcrowding in Lagos did not emerge in 1975, Audu rhetorically writes that, "it is a sobering thought, one that those who think that one more road plan will master Lagos mushrooming growth should take to heart, that the 'growing congestion of the island' was put forward as an objection to Lagos's suitability as early as the $1^{\text {st }}$ of January, 1914 when Nigeria first came into being as a political entity (Ibid. Kirk-Greene, 1968).”

On 9 August 1975, when the debates on the location of the capital of the country had reached a peak, and with the revenues from petroleum exports flooding the country with different kinds of imported goods, the Military Head of State, General Murutala Mohammed, set up an eight member Committee on the Location of the Federal Capital of Nigeria. The task of the committee was to review the multiple roles of Lagos as the federal capital of Nigeria, the capital of the State of Lagos, and the economic capital of the country (Aguda, 1975). The committee adopted a four-step modus operandi in its deliberations. First, in response to the initiative of the military to question the status of the city of Lagos, the committee called for memoranda from the general public in all the major newspapers asking for opinions on the subject of relocating the federal capital or keeping it at Lagos. Second, the committee sought the opinions ${ }^{2}$ A study of Nigeria's national expenditures will show how the budget expanded over the years as the supply of petroleum products to the world market increased. See p. 7, Nigeria, Second National Development Plan, 1970-1974, Second Progress Report; see Page 9 of the Nigeria, Third National Development Plan, 1975-1980; and see p. 3 and p. 49 of Nigeria, Fourth National Development Plan, 1981-1985. Bayo Aadekson's book, Nigeria in Search of a Stable Military System, page 100, is more specific on this subject. Moreover, Louis C. Umeh was specific on the relationships between the planning of Abuja and the oil boom of the 1970s in "The Building of a New Federal Capital City: The Abuja Experience,” in Robert W. Taylor's Urban Development in Nigeria.

${ }^{3}$ It is important to state that the Aguda Committee on the Location of the Federal Capital Report did openly encourage public participation on the subject. The public provided suggestions to the members of the committee through several newspaper articles, public debates, and direct mail. of non-governmental agencies; trade unions; architectural, engineering, and urban planning associations; and prominent personalities in the country. These individuals were from academia and from federal and state government agencies and departments. The country's important traditional rulers-Obas, chiefs, Emirs, and local counselors-were also included. Third, the committee visited all the capitals of the then 19 states of Nigeria in order to interview federal, state, and county officials and those from various agencies. Finally, it visited 14 cities in 8 different countries, which had had the experience of relocating their capital cities during the twentieth century. The cities visited included: Mombassa and Nairobi, Kenya; Livingstone and Lusaka, Zambia; Gaborone, Botswana; Dar Es Salaam and Dodoma, Tanzania; Karachi and Islamabad, Pakistan; New Delhi, India; Sydney and Canberra, Australia; and Rio de Janeiro and Brasília, Brazil (Ibid.).

The committee, led by Federal High Court Justice Akinola Aguda, concluded that a new federal capital would 1) improve Nigeria's national security; 2) enhance Nigerian interior development; 3) encourage the decentralization of economic infrastructure from Lagos; 4) enhance the development of an indigenous Nigerian building culture and industry (O'Malley, $\left.{ }_{1989}\right)^{4}$; and 5) the capital would emphasize the fact that Nigeria had emerged from the Civil War of 1967-70 (which took more than 1.7 million lives) a more united, stable, and confident country ${ }^{5}$. Seeing itself as the United States of Africa, a country with more than 250 distinct ethnic groups, 1975-1979 was the era in which Nigeria revised its constitution and patterned it after the checks and balances system of the United States, which divides power among the legislative (Congress), judicial (Supreme Court), and executive (President) branches.

Nigerian law makers who shared the opinions of the committee, such as Justice Anthony Aniagolu, the Chairman of the defunct Nigerian Constituent Assembly during the Second Republic (October 1, 1979-December 31, 1983), justified the idea of developing a new federal capital by suggesting that there is a fundamental need for a place where all Nigerians could come together on an equal basis to help foster national unity (West Africa, 1989). For Dr. D. S. Tafida, also a former Constituent Assembly member, "Abuja is more important than any state because it symbolizes unity and guarantees our sense of belonging.” Having just come through the bloody and damaging Civil War over Biafran succession, it was felt that while Lagos lies in a heavily Christian and Yoruba part of the country, the federal capital should be independent of any religion or ethnic group (Ibid.). The committee and the advocates of a new fed-

\footnotetext{
${ }^{4}$ It is important to keep in perspective that although the contexts and time frames are different, the reasons that were given by Nigerian authorities have been exploited in different countries when they sought to plan their capital cities. For example, upon reading the history of the development of capital cities such as Washington, D.C., Brasília, Canberra, New Delhi, Pretoria, Islamabad, and a provincial capital such as Chandigarh, such reasons and sentiments were expressed in many ways by the political leaders who planned the cities. See Therese O'Malley et al., 1989, The Mall in Washington; John Epstein, 1973; Norma Evenson, 1969 and 1973; Ravi Kalia on Chandigarh, 1987; James Holston on Brasília, 1989; and Lawrence Vale on Architecture, Power, and National Identity, 1992.

${ }^{5}$ As a nation that emerged out of British colonialism in 1960 and began planning a new federal capital city in 1975, the project was loaded with anticolonialist rhetoric that also carried the undertone of a continent that was in the process of self rehabilitation following the end of colonialism. Nigeria also found increased responsibilities thrust on her as the giant of Africa, with an estimated population of over 90 million people, making her the most populous black nation on the face of the earth and, hence, the flag bearer of all African nations. This is of course a nationalistic sentiment which many African countries would contest in different areas outside population and national wealth.
} 
eral capital city also raised the problems of overcrowding and lack of land for future expansion at Lagos, as well as the existence of severe social inequality in Lagos and other colonial cities of Nigeria due to residential and infrastructural segregation based on race and class (Abu-Lughod, 1980).

Having laid out all the arguments justifying why Lagos should no longer be the capital of the country, the political advocates for the city determined that Abuja should be conceived as a place where Nigeria would show the world that it is free from British colonization, has reformed urban segregation based on race and class, and created a "federal character" with which all Nigerians could identify regardless of their ethnic heritage.

In order to achieve these goals, the committee and its urban planning and design consultant, International Planning Association (IPA) of the United States, which developed feasibility studies for Abuja, believed that geographical centralization of the proposed Federal Capital Territory (FCT) was an essential "physical embodiment of the national goals for unity (The Master Plan for Abuja, 1979),” because it symbolized physically the equal accessibility to the government of all the ethnic groups, and that it also provided "a balanced development focus for the nation (Ibid.).”

The Federal Government of Nigeria then produced a schedule for implementing the committee's recommendations on 4 February 1976. Decree No. 6 established for Nigeria a Federal Capital Territory, i.e., an African version of the District of Columbia-a neutral ground where a Nigerian "federal character" would be developed for the good of all Nigerians (Decree Number 12, 1976; Constitution of the Federal Republic of Nigeria, 1979) ${ }^{6}$. The government took an 8000 sq. kilometer parcel (about 3088 sq miles, which is over twice the size of the State of Lagos, or about $2 \frac{1}{2}$ times the size of Rhode Island) out of three states largely inhabited by minority ethnic groups in the center of the country, a strategy designed to deny any state the claim to the future Federal Capital Territory. Within the territory, Abuja is located on the Gwagwa Plains in the middle of Nigeria. The vegetation is predominantly Savannah-type, and its high elevation and numerous hills give the region a pleasant climate year round, which was one of the major attractions that influenced the committee to select the site (Decree Number 12, 1976; Constitution of the Federal Republic of Nigeria, 1979) ${ }^{7}$.

\section{Using Modernism, as Well as Christian, Islamic, and Ancestral Visual Icons, to Contest Economic and Political Power at Abuja}

Shaped like a heart that is located in the center of the Nigerian nation, Abuja was officially designated as the Federal Capital Territory (FCT) prior to its construction. Within the Federal Capital Territory, there is the Federal Capital City

\footnotetext{
${ }^{6}$ See the Constitution of the Federal Republic of Nigeria 1979, Chapter One, Part I, Chapter VIII, Part I., and First Schedule, Part II. The geographical boundaries of the Federal Capital Territory were clearly delineated. See Appendix 3.

${ }^{7}$ A point that should not be overlooked is: the creation of Abuja was part of the major post-civil war national restructuring efforts by the military juntas. One major aspect of the restructuring was the need to keep the federal government of the country the supreme power by gradually fragmenting the major ethnic constituencies of the country into multiple states with their own identities and names regardless of the fact that they shared common languages. Hence, one could see why Yorubaland was subdivided into more than six states, Igboland, into more than four states, and the north, into about 12 states regardless of the fact that the Hausa language is seen as the major language of communication throughout the vast region.
}

(FCC). Designed for 3 million inhabitants, the FCC is divided into districts that include: the Three Arms Zone, the Ministerial Zone, the Central Business District, Diplomatic Zones, and residential zones, which were planned as sectors for 200,000 to 250,000 inhabitants (The Master Plan for Abuja, 1979). Numerous satellite towns that were planned simultaneously with the FCC are located along the major expressway that transverses the territory in a north-south direction and connects the town of Lokoja with the city of Kaduna. The satellite towns were planned as preventive measures against the problems of overcrowding in the FCC and FCT as a whole. These satellite towns are in different stages of development, and some are highly specialized in function. For example, the town of Sheda was planned primarily for research institutions, which are charged with technical and national development plans, and its residents are primarily academics and scientists. On the other hand, some of the other satellite towns were intended for the relocation of the displaced inhabitants whose lands were taken for the construction of the city and territory. Many of the rest of the towns were developed for different grades of federal government staff and bureaucrats (TADCO Consultants, 1986; Masree Plan for Gwagwalada, 1980; Kaduna Polytechnic, 1985; Greater Usuma Town, 1985; Federal Capital Development Authority, 1989; Niger Consultants, 1986).

The actions of the Nigerian authorities in this regard suggest they were keen to build the satellite towns because of lessons learned from the experiences of Brasília and Chandigarh, where there were not enough housing amenities for low-income residents who had migrated to the newly planned cities. Also, the master plan for the FCT and FCC calls to mind the master plan, which Le Corbusier prepared for his visionary "Experimental City" for 3.1 million inhabitants, in which he located the residential facilities for the elite within the city center, while lower income groups were provided accommodations in the city's periphery (Evenson, 1969; Blake, 1976; Fishman, 1999). Today, reality in Abuja reflects this vision in that middle and lowincome earners cannot afford housing within the FCC. Only millionaires, high-level government officials, and diplomats can afford that luxury (Elleh, 2001). This is in stark contrast to the major social objective of equal access that inspired the creation of Abuja. Poor housing facilities for the colonized subjects and segregation based on class and race during colonial times was often a major point of contention between the colonial authorities and the African populations whom they ruled. One would imagine such extreme social inequalities would be avoided at Abuja, but that is so far not the case. It means that the Nigerian officials who led and supervised the planning process with regard to Abuja have failed to take a leaf from critical texts on colonial architectural policies in Africa (Abu-Lughod, 1980; Robinow, 1989; Wright, 1991; Çelik, 1997) ${ }^{8}$.

\footnotetext{
${ }^{8}$ The "European Quarter" was a common part in all European designed cities in Africa during the colonial era. See Janet Abu-Lughod, 1980. This study explores the consequences and the sources of the segregated cities of Morocco, especially Rabat. See also Paul Robinow, "Techno-Cosmopolitanism," in French Modern. 1989, who details how General Lyautey, the French Governor General of Morocco initiated and executed a number of urban planning schemes in the country. These schemes completely restructured Moroccan cities, like Rabat, Fez, and Casablanca, into old and new twin-cities with unequal distinct characters in terms of social amenities. See as well Gwendolyn Wright, "Introduction," in The Politics of Design in French Colonial Urbanism, 1991. Wright explores how the urban projects of France in the colonies were a well coordinated effort at the highest level of the French government for the purposes of building a greater France. Finally, Zeynep Çelik's Urban Forms and Colonial Confrontations, Algiers Under French Rule, Berkeley, 1997 is useful in this context.
} 
Modernist urban design schemes, such as the Le Corbusier inspired master plan for the Experimental City, did not get implemented in the Abuja master plan by accident. First and foremost, the process of building the city was from the beginning an international business effort that is tied to the petroleum economy. For that reason, designing, building and developing Abuja involved designers and contractors from different parts of the world, including but not limited to, Japan, the United States, the United Kingdom, France, Greece, Germany, the Netherlands, and, in later years, China and South Korea. The ambitious enterprise attracted the largest construction and infrastructure development corporations from around the world ${ }^{9}$. Perhaps, the most telling part of the influence of Le Corbusier on the project comes from the self-consciousness of the firms that were involved in becoming a part of planning, urban design and architectural history by building from scratch a city on a scale that had never before been achieved in such a short period of time. Thus, besides searching for urban design precedents that provided design ideas for the kind of city that the Nigerian authorities were interested in constructing, the precedents that the architects were studying led them to the experimental urban projects that Le Corbusier had proposed during the second decade of the twentieth century. This is evident in the master plan of Abuja, which details how the principal planners went about designing the city (Master Plan for Abuja, 1979).

To begin, the master plan for the FCT and FCC was prepared by the prominent Philadelphia-based firm of Wallace, McHarg, Roberts, and Todd, Inc. The firm planned the whole Federal Capital Territory and laid out the location of the Federal Capital City, i.e., the central city of the territory. Thereafter, Kenzo Tange of Japan prepared the detailed master plan of the city itself and determined the relationships of the whole to its component parts: the residential, business, ceremonial, cultural, and diplomatic zones of the FCC. Tange was also in charge of designing most of the national buildings within the Three Arms Zone, the Ministerial Zone, and the Central Business District. It is also useful to mention here that Abuja's Three Arms Zone is a latter version of Brasília's Triangle of Powers, where the Presidency, the Legislature, and the Judiciary are located. The difference is that Abuja's Three Arms Zone is a circle that is 1 kilometer in diameter instead of the triangle, which Lucio Coasta designed for Brasília.

The satellite town, highway system, and development zone master plans were prepared by Constantinos Doxiades, while the layout for the resettlement towns and some of the experimental residential districts were designed by Milton Keynes Development Corporation of the United Kingdom (Dynasys, 1992). Although these great architects, planners and urban designers were determined to focus their energies on designing and developing the new FCT and FCC, the nature of their contracts with the Nigerian government, the principal patron of the Abuja project, co-opted their designs and transformed them into ideological instruments of the social, political and economic

\footnotetext{
${ }^{9}$ The presence of different planning firms from around the world from the beginning of the project confirms the international dimension of the Abuja development experience. For example, the Consortium, IPA, which was lead by Wallace, McHaag, Roberts, and Todd of Philadelphia, consisted of three American planning firms. Doxiades of Greece and Milton Keynes Development Corporation of UK, as well as Kenzo Tange of Japan all worked simultaneously on the project during the initial stages. When Construction began, Figero, a French based firm and Julius Berger, a German Construction giant in addition to firms from the Netherlands, China, and South Korea were/are still in Abuja.
}

hierarchal struggles that were already in progress throughout the nation before the Abuja project began. Thus, the struggles became apparent in the designs of the internationally renowned architects and planners as they implemented the wishes of the Nigerian postcolonial leaders who employed them ${ }^{10}$.

\section{The Contest for Economic and Political Dominance at the Three Arms Zone}

Studying the architectural and national monuments that have been built in the Three Arms Zone reveals that all the reasons provided by the Aguda Committee for the relocation of the capital were guises for masking the economic and political struggles that were going on in the country among different interest groups. What was at stake was the knowledge that whoever controlled the political center of power would control the resources of the country-especially the vast petroleum and natural gas resources. However, the Nigerian authorities masterminding the Abuja project did not want to convey that message to their citizens. They wanted the public to believe that they were acting in the name of justice, common good, and Nigeria's unity and nationalism (Nigerian Tribune, 1975; New Nigerian, 1975) ${ }^{11}$.

When Kenzo Tange was commissioned in 1978 to design the National Assembly Building in the Three Arms Zone, he started the project with the belief that the National Assembly Complex would be "the most important symbol of the new capital (Tange, op.cit.).” Tange's challenge was how he could design the Nigerian Senate and the House of Representatives in order to realize a building that is articulated with symbols that would project a sense of democracy to all Nigerians. Tange went to different parts of Nigeria and adopted ethnic motifs that are used in wall decorations, ritual practices, and textiles for his design of the complex. Such traditional symbols are icons with which most Nigerians can connect to the buildings regardless of the policies that succeeding governments might implement. A salient point to note here is that Tange's journey to the nation's various indigenous cultures as a source of visual elements was an effort to democratize Abuja's monumental buildings and

\footnotetext{
${ }^{10}$ One piece of evidence of the struggle in the built objects is the changes that were made after Tange departed the scene following the military coup d'état that overthrew the government of the elected President, Shehu Shagari on 31 December 1983/1 January 1984. While the original contract was for Tange to design all the ministerial buildings, the Nigerian authorities quickly changed the contract and began to design different styles of ministerial buildings outside of what Tange had proposed. Such fragmentation was done specifically for the purposes of redistributing the lucrative contracts for the design of the federal ministerial buildings. This seriously undercut a uniform aesthetic around the national mall. Here, one can cite as a specific case the alteration to the design of the Ministry of External Affairs and the Executive Office of the President, which was later designed by Albert Speer of Germany.

${ }^{11}$ The Nigerian authorities, especially, the military, had reason to hide the commercial dimensions and motives of the project. However, one can point to the excessive importation of cement from abroad as evidence that the military juntas were already using the oil money for their own profit. The over importation of cement and the congestion of the seaports throughout the country were clearly signs that the military was anxious to take advantage of nationalism in order to create a grand construction scheme. Thus, Abuja provided the perfect cover for their commercial intentions. Details of excessive cement import were released by the then Minister of Transport, Lt. Col. Yar' Adua, on 31 October 1975. See the Nigeria Tribune, 31 October 1975, cover page. He called it "a world wide conspiracy to sabotage the Nigerian economy.” The cement importation was widely covered in the Nigerian press including the Nigerian Ports Authorities documentation reported by the New Nigerian newspaper on Tuesday, 6 August 1975, page 20.
} 
make them as relevant to local traditions as he could. In this process, however, he also neutralized the ethnic identities of the symbols for his design by combining elements of wall decorations from the housing types of different ethnic groups. This was a conscious act, and an important one, not only in his attempt to use ancestral motifs, but also to use them in a way to bring Nigerians of all ethnic groups and religions together Rosenblum, 1996; Ozenfant, 1952; Vogt, 1996; Togovnick, $1990)^{12}$.

From his travels around the country, Tange was aware that wall decoration is an important aspect of architectural articulation in Nigeria (Goldwater, 1986; Rosenblum, 1969; Crow, $1985)^{13}$. Its most distinguishing characteristic is the multiple designs, which vary among Nigeria's 250 ethnic groups. In southern Nigeria, for example, the art of wall decoration is described as uli among different Igbo speaking groups. "Traditional uli was employed in many social situations, such as at title taking, marriage, memorial services for the dead, and harvest rites, even if the designs themselves rarely depicted human situations (Ottenberg, 1997)"14. Uli is a black pigment from the bud of a fruit. The pigment is obtained by grinding the seed and pressing the ink out of the wet fiber. The black ink is used for multiple purposes, including body painting and wall decorations, especially on walls, which are built with clay. The art of uli functions as a medium for personal expression, and it is essential for resolving certain cultural and political anxieties that are linked to national identity and quotidian cognitive culturally based experiences among the Igbos. Clay is a suitable material for the manipulation of colors. The most common method of applying clay plaster is by natural movement of the builder's hand, sometimes with the aid of a sponge or other soft material that helps to produce the desired effects and symbols (Dike and Oyelola, 1998). While uli practices are common in the south, similar traditions for house decoration deploying different geometrical elements are also common in northern Nigeria. Just as in the south, where the well-to-do and the middle class have started to utilize paints and concrete materials in order to achieve visual effects that evoke traditional clay building techniques, in the northern parts of the country, the transition from the use of only clay and adobe construction methods is also quite visible. For example, in the city of Zaria, located forty minutes from Abuja, the wall that surrounds the Emir's palace was originally built with clay materials. In its recent reconstruction, however, it was rebuilt with cement and quarried stones. Nevertheless, the traditional designs that appealed

\footnotetext{
${ }^{12}$ There is another way of looking at Tange's search for native design elements. Modern art has always borrowed from cultures that it considers "primitive" in order to reinvent itself as something new. Here, the works of Robert Rosenblum Cubism and Twentieth Century Art, 1966/2001; Foundations of Modern Art, Ozenfant, 1952; Adolf Max Vogt's Le Corbusier, The Noble Savage "Toward an Archeology of Modernism," 1996; and Marianna Togovnick’s Gone Primitive: Savage Intellects, Modern Lives, 1990, discuss precedents in such adventures by modernist architects and artists.

${ }^{13} \mathrm{~A}$ lot has been written on the appropriation of ideas and forms from the so-called primitive to the high modern. See Robert Goldwater, "Romantic Primitivism-Gauguin and the School of Pont-Aven," in Primitivism in Modern Art, 1986, as well as "Intellectual Primitivism-The Direct Influence of Primitive Sculpture,” in Primitivism in Modern Art in the same volume.; Robert Rosenblum, "The Foundations of Cubism," in Cubism and Twentieth-Century Art, 1960; and Thomas Crow, "Modernism and Mass Culture in the Visual Arts,” in Franscina Francis (ed.), Pollock and After: The Critical Debate, 1985.

${ }^{14}$ The multiple uses of the art of uli have appeared in contemporary Nigerian artistic practices.
}

to Tange appear on the surfaces of the exterior and the interior of the Palace's massive entry pylon. Out of all the motifs, which he selected, the triangular form stood out for him. According to Tange:

In designing this formal monument for a nation, we were very attracted by the traditional primitive Nigerian or African patterns. Triangular shapes can be designed into pyramids and circles. Patterns made up of these elements and the recurring zigzags are very dynamic from the point of view of local custom. That is the reason we incorporated them into our design language (Tange, op.cit.Vol.2).

Unfortunately, the triangular shape which Tange chose for his first design for the National Assembly Complex was rejected by the Nigerian authorities, who feared that it symbolized the Senate and the House of Representative hugging each other in an endless boxing duel. That was not the image they wanted to project to the world after the recent bloody Civil War. In order to appease the demands of his Nigerian patrons, Tange produced a circular, domed design, which simulated the shape of Aso Rock, an important historical symbol in Nigeria, and the traditional hut. This design was approved. However, despite all the work Tange put into the design of this building, future political developments following a military coup d'état on 31 December 1983 produced very different and unforseen results (Tange, op.cit., Vol. 111).

First, upon viewing the National Assembly Complex that was actually built, and finally completed in 1999 during the brutal military regime of General Sani Abacha, who had deposed the democratically elected President Shehu Shagari, one discovers that the edifice reflected most of the colonial memories, which it was supposed to erase. Its dome evokes the dome of a mosque that was designed and built in 1950 by the Public Works Department when Nigeria was still a British colony. This mosque is located in the northern city of Kano, and it is anything but a symbol of Nigeria's national unity. When the dome of a mosque from the colonial era appears on the nation's Parliament Building, it raises an alarm to many southern Christian and Animist Nigerians of the possibility that a northern based, Moslem, military and civilian intelligentsia, to which the late Abacha belonged, would dominate Nigeria’s political and artistic culture. It begs for an explanation regarding why the original modernist-inspired design by Tange was suddenly abandoned in favor of a design that was approved by fiat by an unelected, military junta, which had muscled its way to the political apex of the country through a military coup d'état (New York Times Magazine, 2002; Mabogunje, 1999) ${ }^{15}$.

One could also speculate that had President Shagari completed his second term in office, the National Assembly Building would have been built in his idealized nationalist image,

\footnotetext{
${ }^{15}$ The differences in religion between the north and the south have always been a source of contention. As recently as 2000 to 2003, many northern states in the Nigerian federation adopted sharia law running parallel to the constitutional laws that bind the country. The case of Sufiya, a woman who was sentenced to death by stoning, received wide press attention as barbaric around the world, but internally, it was more illustrative of how the south opposed the northern way of handling social issues. See The New York Times Magazine, January 2002, pages 28-30. At the heart of this is resource control through the control of federal power at Abuja. Some of these issues are now being described by Nigerian pundits as failures of the Abuja project. See Akin L. Mabogunje, "Abuja: The Promise, the Performance and the Prospect," a paper presented at the workshop on the review of Abuja Master Plan organized by the Ministry of Federal Capital Territory in Abuja in late 1999
} 
which Tange was so dedicated to and remarkably able to provide (This Day, 2005) ${ }^{16}$.Also, one might add that Tange's modernist design could have removed most of the religious tensions that were evoked and provoked by the completed structure. By deliberately avoiding the architecture of any specific ethnic group, Tange managed to create a neutral architectural vocabulary with which many Nigerians could identify, regardless of their ethnic or religious affiliation. Moreover, one can argue that, while not espousing any religious affiliation, Tange's modernist-inspired neutral design appealed to the Christian communities who saw it as the emblem of modernization and new civility for their country. If that were the case, the large Moslem communities, whose social and cultural affiliations have been with the Islamic states of North Africa and the Gulf, were probably lukewarm about Tange's design as it indirectly evoked Euro-American Christian modernism.

Tange's design also suggests that the elected civilian administration of Shagari was more conscious and sensitive to the issues of national unity than the military regime of Sani Abacha, which succeeded it. The Abacha regime wanted to cement what the northern establishment conceived as its national victory in relocating the capital of the country from Lagos to Abuja by imposing a mosque-like form on the National Assembly edifice. However, the visual meanings of the building only succeeded in heightening the anxieties of the large Christian communities in the country. Moreover, the mosque-like form of the National Assembly structure inspired the southern political elite to see the relocation of the federal capital of the country from Lagos to Abuja as a shift of political power from the south to the north, which is primarily dominated by Moslem communities. Along this line of thinking, there are southern leaders who would go so far as to argue that Abuja signifies the trophy, which the north gained by winning the 1967-1970 civil war. Consequently by locating the nation's capital in the north, the revenues that accrue from the vast petroleum resources of the country, which come primarily from the southern delta states, are been siphoned off to develop the northern part of the nation. In addition, the completed National Assembly Building, so different from the one originally designed, also calls attention to a governmental lack of governance and accountability, as well as to issues relating to law and order and the responsibilities of national leaders to obey laws that are enacted by the Assembly (Idris, 1975; Benson, 1975; Onun, 1975; Eke, 1975; Afilakalaka, 1975; Omumu \& Boji-Boji, 1975) ${ }^{17}$.

The ideological confrontation at the Three Arms Zone reached

\footnotetext{
${ }^{16}$ This is not mere speculation. Since a civilian regime returned to power under President Obasanjo, the Minister of Federal Capital Territory, Mallam Nasir el-Rufai, has been talking about returning Abuja to its original master plan. His efforts towards this include demolishing houses that were built on lands that were earmarked by Tange as parklands. While he cannot demolish the National Assembly Complex, his efforts and constant enunciations about returning Abuja to its original master plan suggest that civilian regimes, such as the one that President Shagari headed, have had different agendas from the military juntas.

${ }^{17} \mathrm{Like}$ the authors of so many essays written on this subject, Idris made an effort to argue from a historical perspective that Kaduna has always been the intended colonial capital of Nigeria. Thus, moving the capital to Kaduna would be fulfilling a colonial project. See A. M. Idris, "Kaduna as Our New Capital,” New Nigerian, Thursday, 4 September 1975, p.5. Such debates were widely published in Nigerian newspapers. One overriding element the debates had in common was the question of where the capital should be located. Should it be in the North or in the South, or should it remain at Lagos where it was already located? Such debates can be seen as reflecting the struggle for political and economic power within the Nigerian nation.
}

a crescendo when Bruce Igbinideon, a southerner from Edo State, had the opportunity to design a national monument to stand in front of the National Assembly Complex, which many Christians complained was a hallmark of imposition of Moslem inspired culture over the Christian and other non-Moslem communities in the country. Although Igbinideon's sculpture was inaugurated in the year 2000, it was commissioned several years earlier during the military regimes of General Babangida and Abacha, two military juntas, which ruled the country with an iron fist. Identified in the Nigerian press as a symbol of democracy and unity, Igbinideon called the larger-than-life bronze ensemble "The Mandate". 18

Seen from a Nigerian nationalist perspective, one would conclude that Igbinideon's work encapsulates, celebrates, and unifies certain experiences of the cultures of the Nigerian peoples. However underneath the sculptor's nationalist vision is a southern-based ancestrally inspired nationalism that echoes the cultures of the South, particularly that of the Edo speaking part of the Niger Delta. Unlike the mosque-inspired National Assembly Complex, Igbinideon attempted with his ensemble piece to be inclusive of people from the major ethnic groups in the country. A Fulani woman, who could be any sub-Saharan African woman, is nursing a baby while two children cling to her. A woman, who could be either an Edo or Ijaw and from any of the Riverine parts of southern Nigeria, is dressed in a ashoke, the traditional fabric that is worn during ceremonies by many of the cultural groups in the Niger Delta area of Nigeria. She carries a calabash, which is stringed with beads while she dances and shakes the instrument. A figure depicting a Yoruba chief or a Hausa Mallam in his three-piece Agbada is also part of the formation. A Hausa woman who is wearing an elaborate hair ornament is depicted in her skirt, which stands out from her body like an umbrella. The Fulani maid who spends her daily life selling milk, which she carries in a large calabash on her head, is also featured. An Igbo Chief, wearing a woven hat, a jompa made of embroidered textiles, and tying a wrapper, which measures from his waist to his ankles, is also present. This Igbo chief also wears beads, perhaps a gold necklace, and holds a woven fan made from raffia palm. An elephant tusk is slung over his shoulder with his right hand-a sign of initiation and high title in his community. The cowboy, mostly of Fulani and Hausa origin in the north, with his cattle driving cane over his shoulders, is present as well. This man is dressed in a kaftan, which has large airy openings on the sides. The Chief from the Riverine part of the country, dressed in jompa, holding part of his wrapper in display, and a staff in one hand, stands next to a woman from the same part of the country. His buttons are embellished with gold. The last member of the group is a fisherman from the southern coast.

The ensemble has an irony which cannot be overlooked. Igbinideon has deliberately omitted the major political force in

\footnotetext{
${ }^{18}$ Commissioned during the 1990s, particularly after the annulment of the 12 June 1993 national election that would have brought to power the Nigerian businessman, Chief Moshood Abiola, who hales from southwestern Nigerian, one cannot rule out the possibility that Igbinideon, a Southerner, was making reference to the mandate that the people of Nigeria supposedly gave to Abiola, although the military junta refused to acknowledge it. June 12 has remained a major point of contention in Nigerian political discourse since the annulment of the election. Every year, many followers of Chief Abiola commemorate the anniversary. They highlight the point that he died in prison when he refused to give in to the demands of the military rulers when General Sani Abacha was still in power by claiming to be the elected head-of-state.
} 
the Nigerian nation during the period when the National Assembly Complex was under construction at the Three Arms Zone. That is, no military official is represented, although the military has ruled the country for most of the time since its independence from Britain in 1960. Moreover, it was the military that initiated the Abuja project and also gave Igbinideon the commission for the sculpture. Why would Igbinideon exclude the military from the most important sculpture in the nation's center of power? Was it an oversight? More alarming, however, is Igbinedion's omission of the whole Nigerian bureaucratic establishment, which manages the country on dayto-day basis.

From the ensemble, it can be inferred that Igbinideon wished to cast: 1) a symbol of national unity by representing people from different parts of the country; 2) Igbinedion was creating a symbol of a sacred ancestor's ceremonial ritual sword or maceknown as the ada in the Edo language. In Igbinedion's creation, the aggressive posture with which the strong fisted arm held the national mace suggests that he was looking for strong visual rhetoric to confront what he perceived as the military and northern domination of Nigerian politics. Ultimately, one can suggest that Igbinedion understood that the people's power is greater and should be given priority over the power of single junta leaders who impose their aims on the whole society. Yet, one cannot overlook the possibility that he was acquiescing to the fascist ideological tendencies of the military regimes by providing a sculpture that acceded to their rhetoric. Finally 3), Igbinedion was conjuring and evoking the symbol of an ancestor's compound where the sacred ritual sword is kept and protected-usually at the tomb or an ancestor's alter and burial site ${ }^{19}$. While the discussion in previous paragraphs makes it clear that the ensemble has a unifying role, is this mace, no doubt a comment by Igbinideon on his own Edo heritage, really a symbol of Nigeria? A review of the traditional usage of the sword will make this clear.

Usually held by the priests, chiefs, elders, or chosen ones, who also pour libations to the ancestors and the gods, the mace is the final stamp of the gods and the ancestors. The sword affords security to its bearer similar to the kind of security which the pangolin (a toothless mammal like a sloth, armadillo or aardvark) derives from its scales. The Edos use the metaphor of the pangolin, which can coil itself up and cover its flesh beneath resilient scales if it is attacked by a more powerful animal such as the leopard. The metaphor refers to the contests between the Oba of Benin and the minor chiefs, with the Oba being the leopard while the chiefs are the pangolins who had learned to defend themselves from the might of the Oba. Often, the Oba, symbolized as the leopard in many bronze and brass castings, carried the sword, which he used to behead his enemies, just as the leopard was able to tear up its prey with its sharp teeth and mighty claws. A sketch of the burial place of the King of Benin, drawn by the explorer Giovanni Belzoni in 1823, shows an ensemble alter containing the commemorative bronze and brass heads of the ruler's deceased ancestors (Ben-Amos, 1995). Carved giant elephant tusks, the symbols of greatness and power, are placed on the holes on top of the cast heads. Two

\footnotetext{
${ }^{19}$ The roles of the ancestor's alter and the ceremonial swords in Benin royal art have been covered by many scholars, including Paul Hamlyn, Benin Art, 1960. See plate 37 - 38 where the ceremonial swords are represented in plaques. Also, see Phillip J. C. Clark, An Introduction to Benin Art and Technology, 1973 and Epko Eyo and Frank Willett, Treasures of Ancient Nigeria, 1980, p. 139.
}

ceremonial swords are mounted on the walls of the alter (Preston-Blier, 1998). Paula Ben-Amos writes that, "On top of each head rests a carved ivory tusk. In the old days the king used to receive one tusk from every elephant killed in the kingdom; some were sold to European traders during the long years of commerce with the West, others were given as gifts to faithful chiefs, and still others were displayed on the royal ancestral shrines (Ben-Amos, op.cit.).” Ben-Amos' observations are confirmed by Michèle Croquet who writes that depicted at the base of certain of these heads are symbols of the sovereign's power such as leopards, elephant trunks, silurids and crocodiles (Croqet, 1998).

Igbinedion was aware of the historical and symbolic meanings of the mace before he used it at the Three Arms Zone in an ensemble that seemingly unifies the citizens of the country. He understood the counterpoint it would provide to the mosque-like structure that dominates the Three Arms Zone by providing a strong symbol of ancestral culture. This strength comes from the symbolism of the sword. For example, royal stools display the sword. The royal brass stool of Oba Eresoyen, who ruled in 1735, is said to have taken after the royal stool of Oba Esigie, who ruled from the late $15^{\text {th }}$ century to the early $16^{\text {th }}$ century. A great python, the symbol of power, forms the trunk of the stool. Land and water creatures such as frogs are represented on its base. It has several cosmograms, including the Christian cross, the moon, the sun, but also several versions of the ceremonial sword and machetes. Also, the blacksmith's tool, the anvil, as well as the face of a leopard, another symbol of strength, are represented. All are delicately bounded by the symbolic intertwining strings that hold the universe together ${ }^{20}$.

The coronation of the Oba of Benin in 1979 is another instance where one can observe the usage of the ancestor's sword as a symbol of power. In the photographs of that event, Oba Eredua holds the sacred sword in one hand while he takes the oath of office following the death of his father, Akinzua II in 1978. The manner in which Oba Eredua holds the sword can be compared to the central figure in the alter representing his ancestor, Oba Ewaka the II, in the late $19^{\text {th }}$ century. Here, Eweka II wields the sword of power in one hand and holds a Christian cross on the other. One is reminded here that the Portuguese and the Edos have been trading since the $16^{\text {th }}$ century. In the early years, the Portuguese unsuccessfully proselytized to the Edo monarchs and their people. In fact, one monarch was known to have converted to Christianity in the $17^{\text {th }}$ century, but he was soon deposed. As a result of lengthy exposure to the Portuguese, however, even when there were few conversions, certain Christian icons such as the cross were still adopted and incorporated into Edo representations of power. In addition, when a contemporary Oba, Oba Eredua, performs the ritual of driving evil spirits away, his page bears the ceremonial mace ahead of him. The sound of the ivory gong warns the evil spirits to flee as the great Oba approaches with his mighty sword. Dressed in the invincible outfit of his ancestor, the Oba is believed to have superior powers over evil spirits.

\section{Analytical Integration}

In tying the preceding analysis together, it is important to answer three crucial questions. First, how does one read the juxtapo-

\footnotetext{
${ }^{20}$ This is a historical fact that is marked by the explorations of the Portuguese for a sea route to India along the West Coast of Africa. In addition to trade, another consequence of such exploration was the construction of Elmina Castle in Ghana in 1482. Such fortresses were established for trading purposes, and the Kingdom of Benin became a major part of that West African trading connection with Portugal.
} 
sitions of the federal district's master plan prepared by Wallace, McHarg, Roberts, and Todd; Kenzo Tange's detailed planning for the city center and ethnically eclectic unity design for the National Assembly; Constantinos Doxiadis' satellite towns, highways and development zones; Milton Keynes' resettlement towns and experimental residential districts; Sani Abacha's Islamic-inspired National Assembly Complex; and Igbinideon's ancestral sculpture? Second, how do the ideals and the rhetoric of building a place where all Nigerians can come together to debate the issues that affect their lives match the visible conflicts of the master plan, detailed plans, and the monumental government architecture and sculpture of Abuja? Finally, why is it that the Nigerian military sees itself as the institution that is most qualified to enforce the British mandate of unifying more than 250 ethnic groups, instead of the civilians who inherited political power from the British? These will be answered below.

Evidence provided by the monumental architecture realized at Abuja's Three Arms Zone suggests that the intense struggle for social hierarchies and political power among different segments of the postcolonial Nigerian elite, including, but not limited to, the military, national politicians, bureaucrats, chiefs, religious interests, as well as regional and ethnically loyal political groups, can better explain the reasons why there are so many conflicts in Abuja's master planning and realization process. The struggles began from the very moment the British founded the country in 1914 because the amalgamation of the country which involved the unification of people from different geographic, ethnic, and religious groups also facilitated the creation of what can be seen as a Nigerian identity and nationalism among the natives (Kirk-Greene, 1968; Awa, 1964; Rotberg, 1965).

When the British departed the country on 1 October 1960, they handed the government to Prime Minister Sir Abubakar Tafawa-Balewa. Modeling his role after the monarch in the British Parliamentary system, President Nnamdi Azikiwe, popularly known as Zik, held a ceremonial position, while the day-to-day operation of the government rested in the hands of Tafawa-Balewa. Lagos was the capital of the country when the first coup d'état was staged on 15 January 1966. Prime Minister Tafawa-Balewa and many other federal government officials were assassinated that day. Following the overthrow, the State House in Lagos was renamed Dodan Barracks in order to reflect the ideology of military leadership derived from ancient Hausa warriors. Before independence, when Governor-General Frederick Lugard and many other British Governors and Governors-General ruled the country, the State House was called Government House. Lagos was still the seat of the government of the nation when the first military leader of the country, Major General Ironsi, was assassinated on 29 July 1966, and Lieutenant Colonel Yakabu Gowan seized power. He remained in power until 27 July 1975 when the then General Gowon, the man who led the federal government against the Biafran rebels, was overthrown. General Murutala Muhammed, the successor of Gowon, initiated the movement of the capital to Abuja by signing it into law in 1976. However, he ruled for only six months before he was assassinated on his way to the mosque on Friday, 13 February 1976. Muhammed was succeeded by his deputy, the then General Olusegun Obasanjo (having been elected as a civilian president in 1999, Obasanjo is now governing Nigeria for the second time).

Thus, the election of 1979, in which General Obasanjo handed over power to Shehu Shagari, can be compared to a relay race, in which the military's baton, i.e., its political and economic agenda, was handed over to an elected regime. It is, therefore, not surprising that when President Shagari took office on 1 October 1979 his most immediate agenda item was to speed up the movement of the capital from Lagos to Abujaprojected for 1982 inauguration. Before Shagari embarked on the Abuja project, however, he changed the name of Dodan Barracks to State House once again. This change is not mere nomenclature for historical or aesthetic purposes. It represents the intense struggle for power between two opposing sidesthe civilians versus the military association-an unregistered political party. However, Shagari failed to complete his goal for Abuja before he was overthrown on 1 January 1984 by the military regime of General Mohammed Buhari and General Tunde Idiagbon. Once again, after the coup, the public, which had been disenchanted with the short-lived Shagari regime, celebrated in the streets with music and dance, believing that the military had come to rescue it from a corrupt civilian administration. Under Buhari, the State House at Lagos was once again named Dodan Barracks. Buhari wanted to suspend the Abuja project for a while to concentrate on enforcing discipline among the populace and eradicate corruption from the public service. Israel Okoye writes that:

There is no gainsay that the Buhari regime tried militantly to enforce discipline in the Nigerian body politic. The launching of the War Against Indiscipline (WAI) was a major stride in that direction. The desire to inculcate self-discipline and to re-order the ethical orientations of the Nigerian populace occupied much of the attention of the Government (Okoye, 1991).

The Buhari/Idiagbon administration was so obsessed with indiscipline that the policies of the regime became too tyrannical for the nation to withstand. With the heavy and increasing public outcry faced by the regime, the minister of defense, then General Ibrahim Babangida, exploited the situation and staged a successful coup that brought him to power on 29 August 1985.

After three major coup attempts against his regime in Lagos over the next few years, the fear of a fourth attempt that he might not survive inspired Babangida to speed up the evacuation of the Federal Government of Nigeria from the city on 12 December 1991 - the date that Abuja was inaugurated as the country's federal capital. Following the cancellation of the results of the election of 12 June 1993 without any justification, Babangida resigned from office and appointed a powerless interim president, Chief Ernest Shonikon over his rival Chief Moshood Abiola. Six months later General Sani Abacha, Babangida's military right hand man, took over the reigns of power. The succeeding struggle for power among Babangida, Abiola, Shonikon, and Abacha, took place in Abuja, and the struggles among the various interest groups within the country are manifest in the urban design form, architecture and monumental sculpture of the newly inaugurated capital city and its National Assembly edifice.

As an organization whose members want to protect their personal and institutional interests, the Nigerian military prefers coup d'état as a means for usurping political power. After each coup d'état in the nation's history, the leaders have presented themselves as national heroes who rescued the masses from oppressive leaders. The coup plotters often promised the provision of mass employment, free education, healthcare, higher 
wages, political freedom, and "government of the people by the people," and this was certainly so at the time Abuja was conceived in 1975 as Nigeria's future capital. According to Chris Alli (2001: 241):

Coup d'état is a behavioral pattern of actions, conspiratorial in nature, by which an individual or groups with vested interests seek to change by violent overthrow the status quo. In Nigeria's experience, the motivations have been personal ambition, tribal, ideological, hegemonic and regional imperatives. It also has been applied to prevent changes in power nuances and equations (Alli, 2001).

Alli sheds light on the fact that the outcome of each coup d'état has been the entrenchment of the government of a minority at the expense of the majority, and election has been out of the question. The northern dominated military wanted to locate the Federal Government of Nigeria at a place where it felt secure, and Abuja provided a safe haven for that purpose. Abuja was a strategic center that was exploited by the regimes of General Babangida and General Abacha for the purpose of controlling the oil resources of the nation, and for dispatching troops to quell disturbances in other parts of the country whenever the military felt threatened and when the oil installations were under threat by subversive groups. As an ongoing construction site for federal administrative infrastructure, Abuja also provided the military with opportunities for the enrichment of its senior officers and key supporters through the awarding of lucrative construction contracts.

If one can for a moment imagine the Nigerian military outside the usual paradigm of a war-fighting institution, by considering how various segments of the army fought against each other and against democratically elected regimes, one might be able to see that the Nigerian military is more a political association than a national army. As a political association, the Nigerian military can be compared to powerful national trade unions such as the Academic Union of University Lecturers, the Nigerian Teachers' Union, the Nigerian Doctors' Union, the Nurses Union, the Transport Workers Union, the Oil Workers' Union, and the Plumbers' Union. Each of these unions can go on strike. They are able to shut down their branches, and their strikes have ripple effects on other industries. Such ripple effects can essentially paralyze several activities in the country if the government does not act quickly and appropriately. As trade unions, they use their power to bargain for their economic and political agendas.

The oil revenue enabled the Nigerian military to coalesce into a political association (class) and to carry out its own economic agenda. This is a widely held view by scholars of Nigerian history such Major General James J. Oluleye, 1985; Siddique Mohammed and Tony Edoh, et al., 1986; Israel Kelue Okoye 1991; Cyruk, Ndoh, Cletus Emezi et al. 1997; and Femi Aluko, 1998 (Oluleye, 1985; Mohammed \& Edoh, 1986; Okoye, 1991; Ndoh \& Emezi, 1997; Aluko, 1998). These scholars have studied the performance of military administrations in Nigeria, and they suggest that unlike political parties in democratic societies, the Nigerian military does not depend on the peoples' electoral mandate in order for it to assume power. Once in power, it has done everything within its means to legitimize its reign.

\section{Conclusion}

The planning, design, development and construction of the initial phases of Abuja, that is, the period from the promulgation of the project in 1975 to the relocation of the federal government to the Federal Capital District in 1999, saw many administrations. The FCD and FCC was the nation's largest, most expensive and most significant enterprise dedicated to national unity. Nevertheless, this paper has demonstrated that the nationalist undertaking at Abuja, reflected in the architecture of the newly constructed National Assembly Complex at the Three Arms Zone in the new Federal Capital City (FCC) of Abuja and the sculpture accompanying that complex, became, in fact, the means by which the military, when it was in power, civilian regimes, when they ruled the country, and various other competing segments within Nigerian society exploited different artistic, architectural and urban design vocabularies for the purpose of consolidating their political, social and economic agendas.

\section{REFERENCES}

Aadekson, B. (1981). Nigeria in search of a stable military system. Boulder Colorado: Westview Press.

Abu-Lughod, J. (1980). Origins of urban apartheid. In Rabat, urban apartheid in Morocco. Princeton: Princeton University Press.

Afigbo, A. E. (1986). Federal character: Its meaning and history. Owerri: Rada Publishing Company.

Afilakalaka, (1975). Federal Capital-Kaduna or Lagos? Nigerian Tribune, 11 September 1975, 4.

Aguda Committee. (1975). Location of the federal capital report. Lagos: Department of Information.

Ajayi, J. F. (1984). Problems of National Integration for Nigeria: A Historical Perspective, Distinguished Lecture Series, No. 11. Ibadan: Nigerian Institute of Social and Economic Research.

Alli, M. C. (2001). Federal Republic of Nigerian Army. Lagos: Malthouse Press.

Aluko, F. (1998). Nigeria in search of a leader. Akure: Flocel Publishers.

Audu, I. S. (1974). Foreword. Dialogue on a New Capital for Nigeria: A Political Analysis by Rt. Hon. Dr. Nnamdi Azikiwe, with Translation in Hausa, Igbo, and Yoruba, Zaria: Ahamadu Bello University Press.

Awa, E. O. (1964). Federal government in Nigeria. Berkeley: University of California Press.

Ben-Amos, P. (1995). The art of Benin. London: Thames \& Hudson.

Benson, T. O. S. (1975). A central place is imperative. Nigerian Daily Times, 25 August 1975, 17.

Blake, P. (1976). The master builders, le corbusier, mies van der rohe, and frank lloyd wright. New York: W.W. Norton \& Company.

Çelik, Z. (1997). Urban forms and colonial confrontations, Algiers under French rule. Berkeley: University of California Press.

Croquet, M. (1998). African royal court art. Chicago, IL: University of Chicago Press.

Crow, T. (1985). Modernism and mass culture in the visual arts. In F. Francis, (Ed.), Pollock and after: The critical debate. London: Harper and Row Publishers.

Dark, P. (1969). Benin art. London: Paul Hamlyn.

Dark, P. J. C. (1973). An introduction to Benin art and technology. Oxford: Clarendon Press.

Dike, P. C., \& Oyelola, P. (1998). The Zaria art society. Lagos: National Gallery of Art.

Dovey, K. (1999). Framing places: Mediating power in built form. London: Routledge. doi:10.4324/9780203267639

DRI (1992). Abuja, Federal Capital City, Parkway System Phase 2 Final Report: Detailed Site Development Planning and Preliminary Engineering Design. Nigeria: Dynasys Resource Company.

Eke, P. Y. (1975). Is Lagos a city where nothing works? Nigerian Tribune, 30 December 1975, 5.

Elleh, N. (2001). Abuja: The single most ambitious urban design pro- 
ject of the $20^{\text {th }}$ century. Weimar: VDG

Epstein, D. G. (1973). Brasília, plan and reality: A study of planned and spontaneous urban development. Los Angeles, CA: University of California Press.

Evenson, N. (1973). Two Brazilian capitals: Architecture and urbanism in Rio de Janeiro and Brasília. New Haven: Yale University Press.

Evenson, N. (1969). Planning and cities: Le corbusier, the machine and the grand design. New York: George Braziller, Inc.

Eyo, E., \& Willett, F. (1980). Treasures of ancient Nigeria. New York: Alfred A. Knopf, Inc.

FCDA (1986). Kubwa resettlement area master plan. Lagos: Federal Capital Development Authority.

FCDA (1979). The master plan for Abuja, the new federal capital of Nigeria. Lagos: The Federal Capital Development Authority.

FCDA (1980). The master plan for Gwagwalada. Lagos: Federal Capital Development Authority.

Fishman, R. (1999). Urban utopias in the twentieth century, Ebenezer Howard, Frank Lloyd Wright, Le Corbusier. Cambridge, MA: MIT Press.

Goldwater, R. (1938). Intellectual primitivism : The direct influence of primitive sculpture. In Primitivism in modern art. Cambridge: Belknap Press of Harvard University Press.

Goldwater, R. (1938). Romantic primitivism-Gauguin and the school of Pont-Aven. In Primitivism in modern art. Cambridge: The Belknap Press of Harvard University Press.

Government of Nigeria (1979). Constitution of the Federal Republic of Nigeria 1979, Chapter One, Part I, Chapter VIII, Part I, and First Schedule, Part II. and Appendix 3. Lagos: Department of Information.

Government of Nigeria (1970). Nigeria, Second National Development Plan, 1970-1974, Second Progress Report. Lagos: Department of Information.

Government of Nigeria (1975). Nigeria, Third National Development Plan, 1975-1980. Lagos: Department of Information.

Government of Nigeria (1981). Nigeria, Fourth National Development Plan, 1981-1985. Lagos: Department of Information.

Holston, J. (1989). The modernist city: An anthropological critique of Brasília. Chicago, IL: University of Chicago Press.

Idris, M. (1975). Kaduna as our new capital. New Nigerian, 4 September 1975, 5 .

Kalia, R. (1987). Chandigarh in search of an identity. Edwardsville: Southern Illinois University Press.

Kaduna Polytechnic (1985). Greater Usuma Town (Tourist Resort), Abuja, Site Appraisal Report (Phase 1). Kaduna: Kaduna Polytechnic.

Kelue-Okoye, I. (1991). Soldiers and politics in Nigeria. Enugu: New Age.

Kirk-Greene, A. H. M. (1968). Lugard and the amalgamation of Nigeria. London: Frank Cass \& Co. Ltd.
Mabogunje, A. L. (1999). Abuja: The promise, the performance and the prospect. The Workshop on the Review of Abuja Master Plan. Abuja, 29 November-1 December 1999, 6.

Mohammed, A. S., \& Edoh, T. (1986). Nigeria, a republic in ruins. Zaria: Ahmadu Bello University Press.

Ndoh, C. A., \& Emezi, C. E. (1997). Nigerian politics. Owerri: CRC Publications.

New Nigerian, Tuesday, 6 August 1975, 20.

Niger Consultants (1986). Sheda research town master plan. Lagos: Niger Consultants.

Nigeria Tribune, 31 October 1975, cover page.

Okoye, I. K. (1991). Soldier and politics in Nigeria. Awka: Political Science Unit, Anambara State University of Science and Technology/ New Age Publishers.

Oluleye, J. J. (1985). Military leadership in Nigeria, 1966-1979. Ibadan: Ibadan University Press.

O’Malley, T. et al. (1989). The mall in Washington. New Haven, CT: Yale University Press.

Omum, B., \& Boji-Boji (1975). Removal of federal capital can't solve congestion problem. Nigerian Tribune, 5 August, 1975, 5.

Onun, A. (1975). If Lagos must remain as federal capital. Nigerian Tribune, 22 August 1975, 9.

Ottenberg, S. (1997). New traditions from Nigeria: Seven artists of the Nsukka group.

Ozenfant (1952). Foundations of Modern Art.

Robinow, P. (1989). Techno-Cosmopolitanism. In French modern. Cambridge, MA: MIT Press.

Rosenblum, R. (1960). The foundations of cubism. In Cubism and twentieth-century art. London: Thames and Hudson.

Rotberg, R. I. (1965). The rise of nationalism in central Africa: The making of Malawi and Zambia, 1873-1964. Cambridge: Harvard University Press.

TADCO (1986). Final Land Report: Survey \& Site Analysis, Conceptual Master Plan \& Site Development Plan, Zuba. Sokoto: TADCO Consultants.

The New York Times Magazine, January 2002, 28-30.

This Day, 28 August 2005.

Togovnick, M. (1990). Gone primitive: Savage intellects, modern lives. Chicago, IL: University of Chicago Press.

Umeh, L. C. (1993). The building of a new federal capital City: The Abuja experience. In R. W. Taylor (Ed.), Urban development in Nigeria. Brookfield and Singapore: Ashgate Publishing.

Vale, L. (1992). Architecture, power and national identity. New Haven, CT: Yale University Press.

Vogt, A. M. (1996). Le Corbusier, the noble savage: Toward an archeology of modernism. West Africa, no. 3736, 27 March-2 April 1989, 470.

Wright, G. (1991). Introduction in the politics of design in French colonial urbanism. Chicago: University of Chicago Press. 